\title{
PERAN PENERBANGAN PERINTIS DALAM MENGUBAH PERADABAN PRASEJARAH KE MODERN DI PEGUNUNGAN PAPUA \\ (The Aviation Pioneer's Role in Changing Prehistoric to Modern Civilization in the Mountain Range of Papua)
}

\author{
Hari Suroto \\ Balai Arkeologi Papua Jalan Isele, Kampung Waena, Distrik Heram, Kota Jayapura 99358 \\ Telepon (0967) 572467, Faksimile (0967) 572467, e-mail; hariprimitiveart@gmail.com
}

INFO ARTIKEL

Histori artikel

Diterima: 19 Februari 2016

Direvisi: 11 Maret 2016

Disetujui: 17 Mei 2016

\section{Keywords: \\ Aviation Pioneer, Mountain Range of Papua, Modem Civilization}

Kata kunci:

penerbangan perintis, pegunungan Papua, peradaban modern

\begin{abstract}
The geographical condition of Papua Mountain Range is hard to reach, isolated from the landline, and possessing a community that lives in prehistoric tradition. Airplane becomes the most effective means of transportation to connect the world. This study is aimed to find out the history of aviation pioneer in the Mountain Range of Papua as well as its role in modemizing the local civilization. The methods used in this research are field observation and literature review. The analysis uses historical and contextual environment approaches. Aviation in the Mountain Range of Papua is pioneered by missionaries of Colonial era. The aviation pioneer has opened communication to the word and created new civilization. During its development, өducational and medical facilities, өconomic and govemmental activities are established and centered nearby the airport.
\end{abstract}

\begin{abstract}
ABSTRAK
Kondisi geografis pegunungan Papua sangat sulit dijangkau, terisolasi jalur darat, masyarakatnya hidup dalam tradisi prasejarah. Pesawat terbang menjadi satu-satunya sarana transportasi yang paling efektif untuk menghubungkan dengan dunia luar. Tujuan tulisan ini yaitu untuk mengetahui sejarah penerbangan perintis di pegunungan Papua serta peran penerbangan perintis di pegunungan Papua dalam memodernkan peradaban setempat. Metode penelitian yang digunakan yaitu observasi lapangan dan studi pustaka. Analisis menggunakan pendekatan sejarah dan pendekatan kontekstual lingkungan. Penerbangan perintis di pegunungan Papua dipelopori oleh misionaris pada masa pemerintahan Belanda. Penerbangan perintis telah membuka komunikasi dengan dunia luar serta memunculkan peradaban baru. Dalam perkembangannya didirikan fasilitas pendidikan, kesehatan dan aktivitas ekonomi serta pemerintahan berpusat di sekitar lapangan terbang.
\end{abstract}

\section{PENDAHULUAN}

Lembah Baliem terletak di pegunungan Papua pada ketinggian 1650 meter di atas permukaan laut. Lembah ini membentang sepanjang kurang lebih 60 kilometer dan lebarnya 15 kilometer (Muller, 2009:57). Masyarakat Baliem hingga tahun 1954 masih menunjukkan kehidupan zaman batu (Ngadimin, 1993:93). Pegunungan hijau, terjal dengan jurang-jurang yang dalam dan sempit membentengi Lembah Baliem. Cekungan lembah sungai yang cukup luas hanya terdapat di lembah bagian barat dan lembah bagian timur. Dengan kondisi geografis yang sulit dijangkau dengan jalan darat, maka pesawat masih jadi satusatunya solusi transportasi.

Salah satu moda transportasi yang sangat vital di pegunungan Papua adalah pesawat terbang. Penerbangan perintis di pegunungan Papua masih menjadi tumpuan bagi masyarakat yang tinggal di daerah pegunungan atau terisolasi jalur darat. Penerbangan 
perintis di pegunungan Papua pertama kali dibuka oleh misionaris pada masa pemerintahan Belanda.

Pada awalnya untuk bisa menyapa dan melayani umat di pedalaman dan terisolasi di daerah pegunungan, para misionaris harus berjalan kaki dari satu tempat ke tempat yang lain. Selama berhari-hari, mereka menyusuri hutan di kawasan pegunungan, pindah dari satu kampung ke kampung lain. Agar misi lebih efektif dan efisien, maka mulai sejak itu mulai dilakukan penerbangan dengan menggunakan pesawat kecil dan pembuatan lapangan terbang secara swadaya.

Sebelum lapangan terbang selesai dikejakan, penerbangan $k \boldsymbol{k}$ Lembah Baliem dilakukan dengan pesawat amfibi yang mampu mendarat di permukaan air. Misionaris CAMA (Christian and Missionary Alliance) menggunakan pesawat amfibi Short SA.6 Sealand JZ-PTA, terbang dari Danau Sentani mendarat di Sungai
Baliem pada 20 April 1954. Pesawat ini dipiloti oleh Kapten Al Lewis dan co-pilot Edward W. Ulrich (Lieshout, 2009:28).

Pada 25 Maret 1955 pesawat amfibi jenis Piper PA-20135 Pacer JZ-PTB milik Missionary Aviation Fellowship (MAF) melakukan penerbangan dari Danau Sentani berhasil mendarat di Danau Archbold. Sedangkan pesawat Cessna $180 \mathrm{JZ}$ PTF milik MAF merupakan pesawat beroda yang pertama kali mendarat di Swart Valley sekarang disebut Karubaga, pada 5 Juni 1957. Lapangan terbang Hetigima pertama kali didarati pesawat beroda milik CAMA pada 18 Desember 1956 (Luntungan, 2013:14). Lapangan terbang (airstrip) hasil kerja misionaris kondisinya hanya sekedar ada. Landasan pacu berupa lapangan rumput atau tanah yang diperkeras. Posisi lapangan terbang itu terletak di atas bukit, dan diapit diantara bukit lainnya. Sedangkan di ujung landasan, jurang berdasar sungai bebatuan.

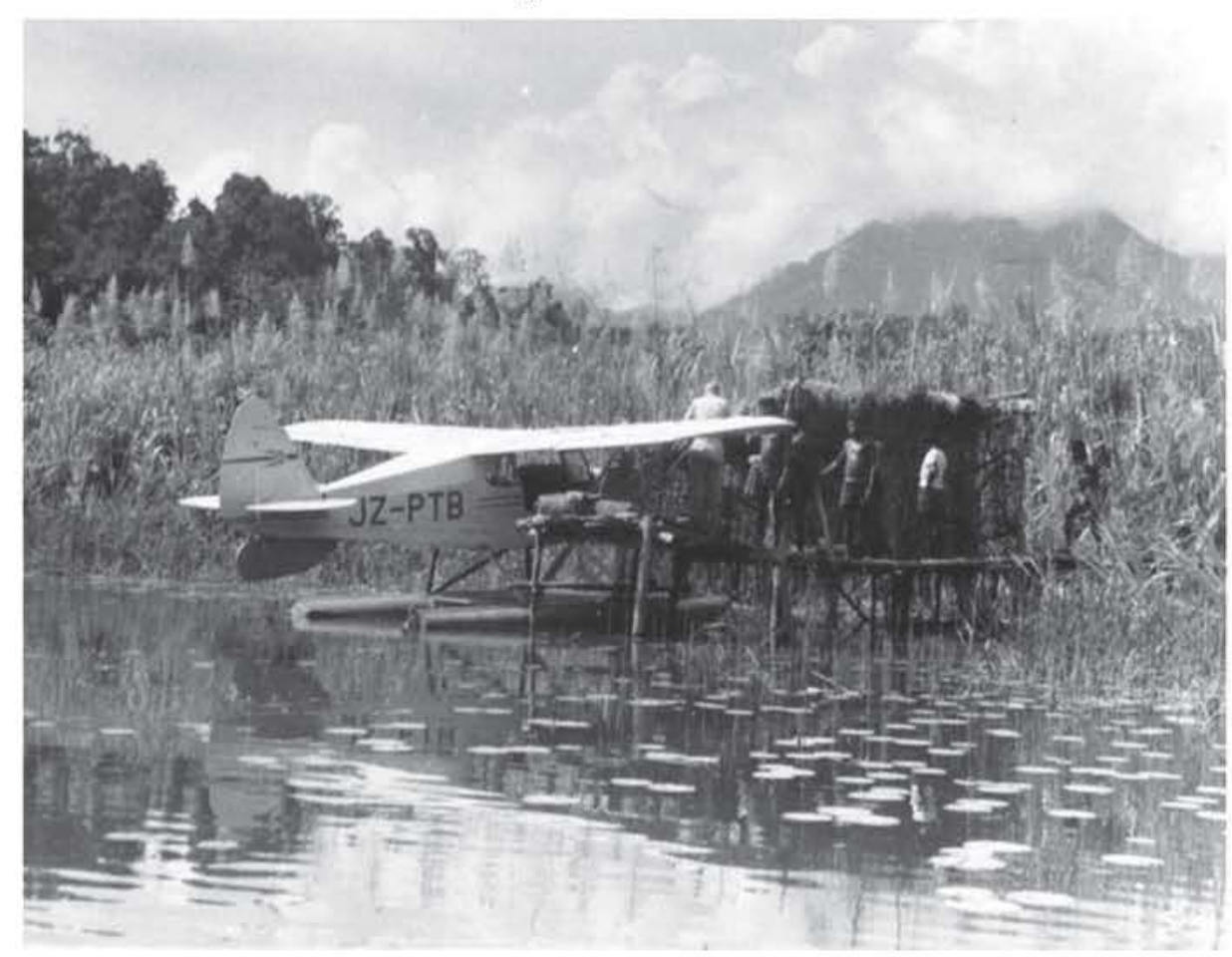

Cambar 1. Pesawat JZ-PTB di Danau Archbold (sumber: http://www. pusatgidi.org) 
Dengan pesawat kecil, para pilot mampu mendarat di lapangan terbang yang berukuran pendek dan sulit. Pendaratan pertama (first landing) selalu merupakan suatu hal yang menegangkan danpenuhresiko.Ketidakrataan yang kecil sekalipun dapat menghancurkan baling-baling. Pada tahun 1950-an dan 1960-an lapangan terbang dikontrol oleh pilot sendiri. Di kemudian hari hal itu tidak lagi sering dilakukan. Para pilot mempercayai para misionaris yang sudah berpengalaman dan pengamatan mereka sendiri dari udara (Reuter, 2010:181).

Transportasi udara dinilai paling efisien dan cepat, pesawat-pesawat kecil dan ringan jenis Cessna caravan dan twin otter berperan penting untuk mengangkut barang, dokumen, bahan pangan, serta penumpang ke tempat terpencil. Sebaliknya, setiap pesawat dari pedalaman mengangkut hasil pertanian lokal seperti sayuran, buahbuahan dan umbi-umbian untuk didrop di Sentani. Transportasi udara sangat berpengaruh pada kelancaran administrasi pemerintahan di pedalaman. Sehingga, komunikasi menjadi semakin lancar dan kehidupan masyarakat di wilayah itu semakin terbuka dan hidup.

Keunggulan pesawat kecil jenis Cessna caravan dan twin otter dapat beroperasi dengan ground equipment yang minim, dan multihop capability fuel tank. Pesawat ini bisa lepas landas dalam jarak pendek, serta mendarat di landasan yang tidak beraspal. Spesifikasi ban pesawat ini mampu mendarat di landasan berumput atau berkerikil serta jarak landasannya sejauh 600 meter.

Gambar 2. Peta Persebaran lapangan terbang di Lembah Baliem (Sumber: http://uww.lepido-france.fr)

Namun, cuaca dan arah angin yang cepat berubah sangat membahayakan keselamatan penerbangan. Kondisi geografis Lembah Baliem dikelilingi pegunungan sehingga setiap pesawat sering mengalami kesulitan dalam proses pendaratan atau tinggal landas. Semua pesawat yang menuju Lembah Baliem harus menemukan pintu masuk lembah, pintu ini merupakan satusatunya jalan utama.

Untuk pesawat-pesawat yang tidak memiliki kemampuan terbang tinggi maka caranya yaitu dengan terbang diantara celah-celah di lereng pegunungan Jayawijaya. Pilot harus piawai mengendalikan pesawat dan meliuk-liuk diantara celah-celah pegunungan. Celah-celah ini disebut sebagai Gap yang dilkuti dengan nama setempat. Beberapa diantaranya adalah Gap Bokondini, Wamena North Gap (Pass Valley) dan lainlain. Salah satu yang populer adalah Gap Bokondini karena posisinya yang sangat menguntungkan dengan kawasan yang cukup luas untuk bermanuver dan secara statistik, cuaca di Bokondini juga mewakili kondisi cuaca di atas Wamena. 


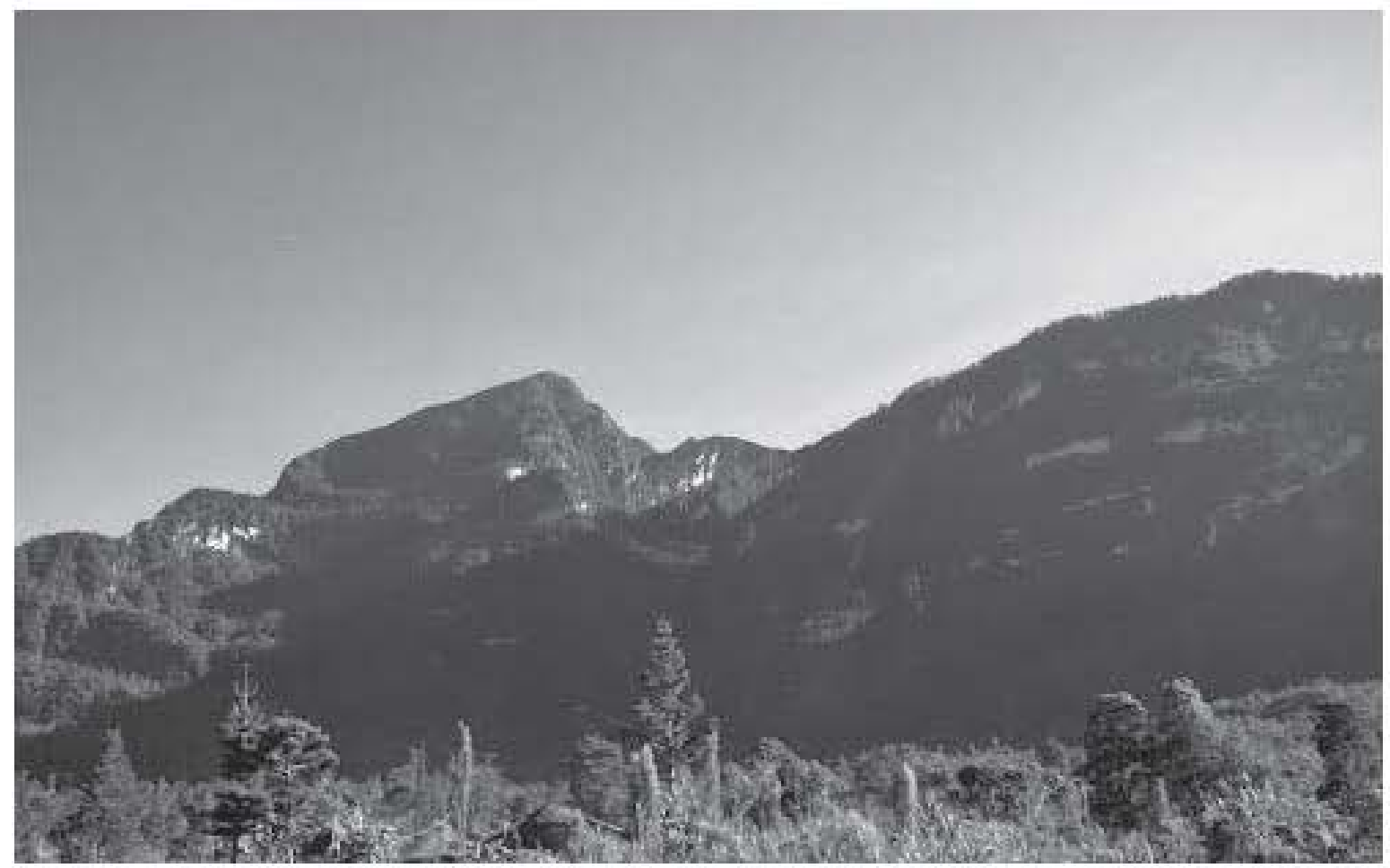

Gambar 3. Wamena Nouth Gap (Puss Vullay) (Sumber. www.panorimlo.com)

Sekallpin pllot blsa menemukan osbuah colah kobang di baweh laplasen awan-awan yang tabal dan blos terus terbang dl bawahnya, den mendarat dengan selamat, tetapleh th seringkall berbahaya. Tak Jarang, pilot mosti berpolut dongen cuecta yang tidak menentu. Apabla awanawan mengantung rondah, maka larak pardang kurang tetap agak gult urtuk membedakan satu lembah darl lembah lainty. Jike becreng pilot tanpe dlsengeja membelok maguk ke gebuah lembah yang akdnimya buntu dan da terlambat meryaderimya, maka itu blaa memyebabkan kecelakasan yang fatel. Itulah yan dialomi pilot Morino Voth pada eagt dia terbang dl berwah Iapisan awan dan komudlen menglra sudeh menemuken jalur terbang masuk ka dakam Lembah Ballem. Dia salah, karende tomyata itu edeloh Lembah Seng. Dalem waktu singkak lembah ltu memyempit dan sebelum ils dapat melekulan apa-epe pesenvalinya kemudlan menabrak gunung (Reuter, 2010:84).
Plict A Lewis dengan perawat amibi Short SA 6 Seeland JZ-PTA makakukan penerbangan dar Sentanl monuju Lombah Ballem pada 28 Aprll 1955, pesewatrye membewa fumltur, bahan makanan, dan bahan bangunan deri aluminium. 8 okitar 40 morit setelah berangkat, Lewls malaporkan bahwa pesawetrya berada dl atas Sungal Idenburg, dengan ketingglan 2750 metar dlatas permulcaan laut ( $m$ dpl), dalam kotdaen hujan lobat. Sekelah th Lewlg kehllangen kontak dengan bandera Sentanl. Pesauratrya mengalami tubulensi dan menabrak gunung dl fhit masuk Lembah Baliom pada kolinggion $3100 \mathrm{~m}$ dpl. Tubulensl terjad dbebabkan oleh ukuran peseawet yang kecll sehingga tidek tahan dengan angin kencang di pegunungan.

Berdasarkan uralan dl atas, dlkotehul bahwa penerbangan perintls itu balah membuka suatu dimensi baru peradaben dl pedalaman Papua yang oolemin ini lidak torhubungkan dongan dunla luar. Tranaportag udara telah 
membuka komunikasi dengan dunia luar serta memunculkan peradaban baru, dari prasejarah ke modern. Dengan kondisi geografis yang sulit dan fasilitas terbatas dibutuhkan perjuangan berat dalam merintis penerbangan ke pegunungan Papua terutama di Lembah Baliem. Sangat menarik untuk mengetahui sejarah penerbangan perintis di pegunungan Papua dan peran penerbangan perintis di pegunungan Papua dalam memodernkan peradaban setempat. Tulisan ini digunakan metode deskriptif kualitatif. Pengumpulan data dilakukan dengan observasi lapangan serta studi pustaka. Analisis data menggunakan pendekatan sejarah dan pendekatan kontekstual lingkungan.

\section{PEMBAHASAN}

Permukaan tanah yang rata di pegunungan Papua sangat terbatas. Pada umumnya lapangan terbang di pegunungan Papua terletak di pinggir tebing dengan salah satu sisinya berupa jurang yang cukup dalam. Melakukan lepas landas atau pendaratan di lapangan terbang perintis membutuhkan keterampilan yang lihai dari pilot. Pesawat harus bisa self starting tanpa bantuan ground support unit. Salah sedikit pesawat bisa tergelincir ke dalam jurang.

Kondisi lapangan terbang ini memberi tantangan tersendiri bagi pilot yang melaluinya. Pilot MAF dilatih untuk terbang di medan berat seperti pegunungan dan daerah pedalaman lainnya serta mendarat dan lepas landas di landasan pendek. Untuk kualifikasi ini, selain handal, misionaris membutuhkan pilot plus, yakni pilot yang bersemangat misioner.

Lapangan terbang hasil kerjasama misionaris dan penduduk lokal terdiri atas lapangan terbang Karubaga
(KBF) terletak pada koordinat $03^{\circ} 41^{1}$ $05^{11} \mathrm{~S} 138^{\circ} 28^{1} 44^{11} \mathrm{E}$ ketinggian 1561 $\mathrm{m}$ dpl, panjang landasan 557 meter lebar enam meter. Lapangan terbang Wamena (WMX) terletak pada ketinggian $1.550 \mathrm{~m}$ dpl dengan koordinat $4^{0}$ $05^{1} 54^{11} \mathrm{~S} 138^{\circ} 57^{1} 98^{11} \mathrm{E}$. Lapangan terbang Elelim terletak pada koordinat $03^{\circ} 47^{1} 00^{11} \mathrm{~S} 139^{\circ} 23^{1} 08^{11} \mathrm{E}$, ketinggian $455 \mathrm{~m}$ dpl, panjang landasan 827 m. Lapangan terbang di Wesaput, panjang kurang lebih 600 meter.

Misionaris APCM secara
swadaya membangun lapangan
terbang Kelila (LLN) pada tahun 1959. Lapangan terbang ini terletak pada koordinat $S 03^{\circ} 43.833^{1}$ E $138^{\circ}$ 42.553 ${ }^{1}$. Berorientasi utara selatan, berada pada $1280 \mathrm{~m}$ dpl. Pengerjaan lapangan terbang ini dikoordinir oleh Bert Power, Lion Delinger, dan Garbert Ericson dengan tenaga kerja penduduk setempat. Alat kerja yang digunakan adalah sekop yang dikirim dari Sentani. Panjang lapangan terbang Kelila adalah 731,52 meter. Lapangan terbang selesai dikerjakan dalam waktu tiga minggu (Suroto, 2014:56) dan diuji coba pendaratan pertama kali oleh pesawat Cessna $180 \mathrm{JZ}-\mathrm{PTF}$ milik MAF dipiloti Dave Steiger.

Lapangan terbang hasil kerja misionaris Jerman Rheinische Missionsgesellchaft (VEM) yaitu Angguruk, Apahapsili (AAS), Pagai, Kosarek, Welarek, Yohosem, Walma dan Panggema. WH Vriend dan Siegfried Zollner mulai membangun lapangan terbang Angguruk pada 19 Mei 1961, empat bulan kemudian lapangan terbang Angguruk dibuka sesudah pilot MAF datang berjalan kaki dari Wamena ke Angguruk untuk memeriksa keadaan lapangan terbang (Zollner, 2006:30), dan pendaratan pertama kali oleh pesawat Cessna milik MAF pada 23 September 1961. 
Membangun lapangan terbang Angguruk bukanlah suatu hal yang mudah bagi pendeta Zoellner dan dokter Vriend, karena dataran tinggi itu sebenarnya terlalu pendek. Setelah $\mathbf{3 8 0}$ meter ada gunung yang menjulang tinggi. Padahal panjang minimal lapangan terbang haruslah 500 meter atau harus memiliki suatu tanjakan yang cukup tinggi di bagian akhir. Bagian akhir lapangan kemudian dibangun dengan memiliki tanjakan sekitar $24 \%$, sehingga total panjangnya menjadi 40 meter (Reuter, 2010:36; Zollner, 2011:22).

Lapangan terbang Angguruk terletak pada koordinat $4^{0} 12^{1} \quad 0.36^{11}$ S $139^{\circ} 25^{1} 58.44^{11} \mathrm{E}$, berada 1400 $\mathrm{m}$ dpl dan dikelilingi oleh gununggunung di atas 2000 meter. Ke arah barat pemandangan lapang dan jelas ke gunung-gunung dengan ketinggian sekitar $\mathbf{4 0 0 0}$ meter dan dibalik gununggunung itulah terletak Lembah Baliem.

Lapangan terbang Apahapsili mulai dibangun oleh Helmut Bentz dan Anton Mansawan pada 10 September 1965 dan pendaratan pertama oleh pesawat Cessna MAF pada 23 Desember 1965. Pada 26 Juni 1969 merupakan pendaratan pertama pesawat MAF di lapangan terbang Panggema (Silak, 2006: 14-19).

Frans van Maanen dibantu masyarakat Kurulu mulai pekerjaan pembuatan lapangan terbang Yiwika pada 18 Oktober 1962. Frans menyerahkan sebuah kapak besi, dua parang dan beberapa mikak (cangkang moluska laut) kepada pemilik tanah (Lieshout, 2009:152).

Misionaris mendirikan gereja, rumah misi, fasilitas kesehatan, asrama dan sekolah di pinggir lapangan terbang. Dalam perkembangannya kemudian di sekitar lapangan terbang, didirikan pemukiman teratur milik warga setempat yang sebelumnya rumahnya terpencar. Itulah cikal bakal pusat hunian di pedalaman seperti Kelila, Wamena, dan Angguruk. Pemerintah Belanda kemudian mendirikan kantor administrasi dan pasar di sekitar lapangan terbang.

Seiring dengan pemekaran daerah, oleh pemerintah daerah setempat, lapangan terbang perintis yang semula hanya untuk melayani penerbangan misionaris dikembangkan menjadi lapangan terbang komersil. Namun perkembangan ini tidak disertai dengan perbaikan fasilitas pendukung sesuai standar keselamatan penerbangan. Lapangan terbang perintis, dengan lebar dan panjang landasan pacu pendek. Terletak di sisi gunung dan permukaan landasan tidak rata, ujung landasan berupa jurang, ujung landasan yang satu lebih rendah, yang lainnya lebih tinggi, untuk take off dan landing hanya bisa dilakukan dari satu arah.

Kondisi landasan terbang perintis masih sangat minim sarana pendukung. Posisi landasan terbang yang tidak lurus dan runway tidak berpagar. Binatang piaraan bebas berkeliaran di sekitar landasan ketika pesawat hendak take off dan landing seolah-olah sudah menjadi hal yang biasa. Take off dan landing juga sangat tergantung pada cuaca. Cuaca di pegunungan sangat sulit diprediksi, mudah berubah dari cerah menjadi berkabut dan hujan dalam sekejap. Terdapat jam-jam khusus daerah tertentu tidak boleh didarati pesawat.

Untuk itu, para pilot harus betulbetul menguasai medan, terutama dalam proses mendekat ke lapangan terbang harus terbang visual. Sebelum terbang, para pilot harus mengetahui betul lokasi yang dituju dan jalur penerbangannya. Pada umumnya 
lapangan di daerah pegunungan bisa untuk landing rata-rata di bawah pukul 10.00 pagi, karena saat itu angin lebih tenang, diatas pukul 10.00 sudah tertutup awan yang tebal.

Pada musim penghujan, landasan pacu sebagian tergenang air. Sesaat sebelum pesawat itu berhenti roda-rodanya terjerumus dalam sebuah bagian tanah yang lembek dan tertanam. Pesawat yang tiba-tiba berhenti dengan cara itu terangkat bagian belakangnya dan dengan perlahan terjungkir, seperti dialami pilot Al Lewis (Reuter, 2010:182). Pesawat tidak boleh mengangkut beban melebihi batas muatan tertentu agar tetap bisa take off dan landing. Hal ini terjadi karena kondisi landasan yang lembek.

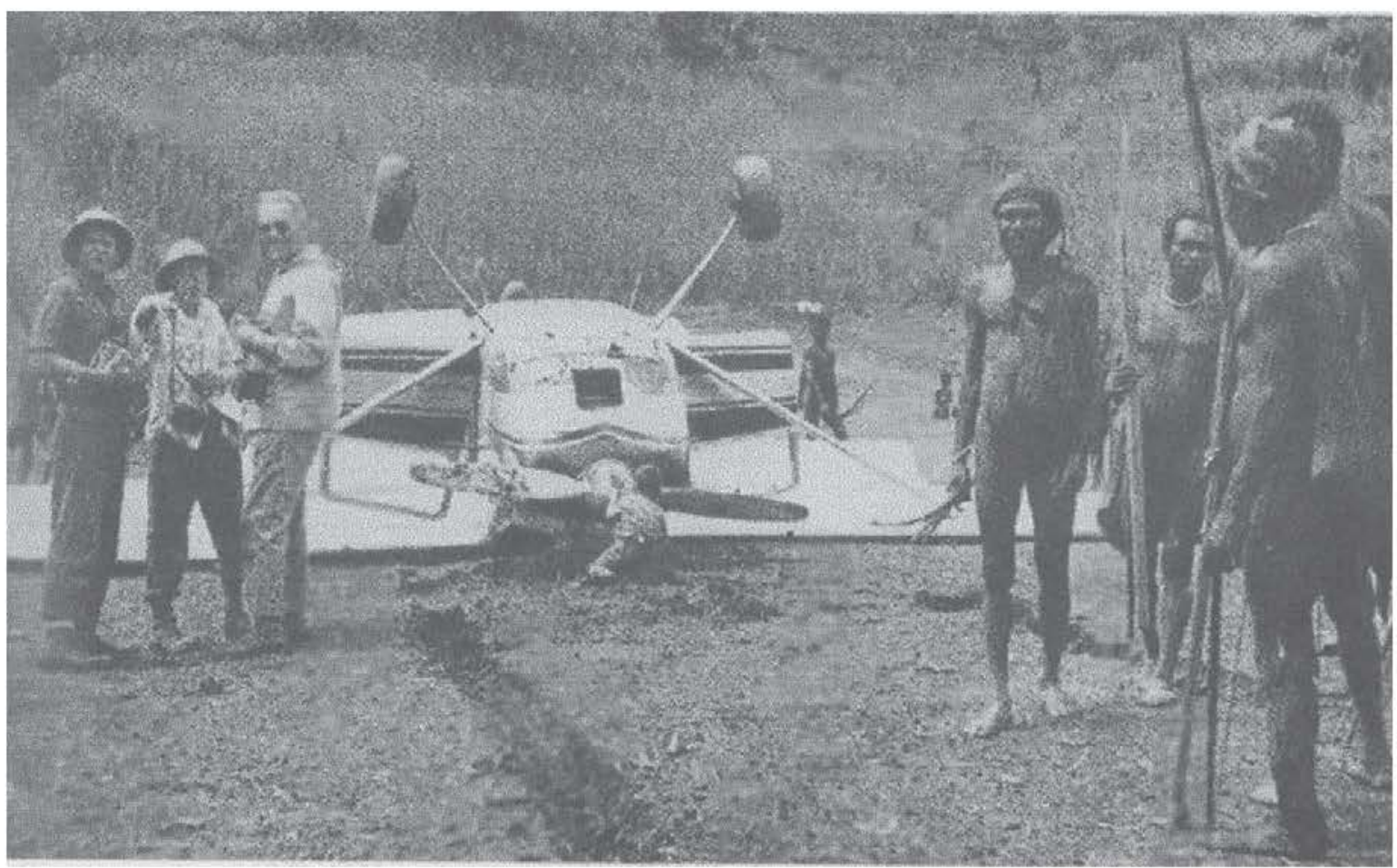

Gambar 4. Pilot Al Lewis mendarat terbalik

(sumber: Hitt, 1962: 64)

Tipe landscape pegunungan juga menjadi faktor utama penyebab terjadi jatuhnya pesawat. Kondisi cuaca di suatu lokasi yang cepat sekali berubah, alat-alat di bawah untuk memandupesawatmasihsangatminim. Fasilitas meteorologi di pegunungan yang sangatminim sehingga penerbang tidak bisa mengetahui kondisi cuaca di sepanjang rute penerbangannya. AMA meminta bantuan tenaga lapangan dari masyarakat lokal yang ada di sekitar lapangan terbang. Tenaga lapangan dilengkapi handy talkie dan radio komunikasi yang setiap saat melaporkan kondisi cuaca ke kantor pusat AMA di bandara Sentani.

Perubahan cuaca, seperti pembentukan awan, kabut tebal, atau hujan, sangat menghambat daya pandang. Akhimya, meningkatkan risiko penerbangan. Lapangan terbang perintis di pegunungan tidak dilengkapi fasilitas meteorologi, sehingga sangat terbatas kemampuannya untuk mengukur indikator cuaca secara akurat dan tidak mampu melakukan prakiraan cuaca. itu tidak memiliki fasilitas navigasi.

Belum semua lapangan terbang yang ada di pegunungan Papua 
dilengkapi dengan communication chanel. Hal itu karena kondisi kontur wilayah dan geografis yang tidak mendukung. Untuk mengubah lapangan terbang tersebut menjadi layak dan aman digunakan tidaklah mudah. Sebab, tidak ada lahan yang cukup untuk memperluas lapangan terbang. Tantangannya ada, lapangan terbang di pegunungan tidak bisa diperpanjang atau diperluas karena letaknya ada yang di puncak dan lembah.

\section{PENUTUP}

Penerbangan perintis di pegunungan tengah Papua dipelopori oleh misionaris, yang pada awalnya guna mendukung misi pekabaran Injil. Lapangan terbang yang dibangun merupakan hasil kerjasama dan swadaya antara misionaris dan penduduk lokal pada masa pemerintahan Belanda. Selain membawa penumpang, pesawat misi membawa barang-barang untuk didistribusikan. Penerbangan perintis telah membuka komunikasi dengan dunia luar serta memunculkan peradaban baru, misalnya dunia pendidikan. Misi tersebut mendirikan gereja, sekolah dan asrama di pinggir lapangan terbang. Akhirnya kawasan itu berubah
Setelah peralihan pemerintahan Belanda ke Indonesia, pemerintah Indonesia memperpanjang landasan terbang perintis Wamena yang semula 600 meter menjadi 1.550 meter. Lapangan terbang ini juga dilengkapi fasilitas tower dan fasilitas komunikasi modern. Lapangan terbang perintis Wamena berubah status menjadi bandara komersil dengan jadwal penerbangan teratur dan mampu didarati pesawat ATR, C-130 B Hercules dan Cessna 402 B.

dalam peradaban modern masyarakat Papua.

Layanan penerbangan perintis di pegunungan Papua harus mendapat perhatian. Pemerintah wajib meningkatkan infrastruktur navigasi dan panduan untuk pendaratan (approach guide). Dengan begitu, pesawat-pesawat dengan rute pegunungan dapat memanfaatkan instrumen navigasi (instrument flight rule) yang lebih andal dan akurat. Perlunya diberikan apresiasi kepada para misionaris, karena tanpa mereka tidak ada lapangan terbang dan akan sulit untuk menjangkau daerah pedalaman. 


\section{DAFTAR PUSTAKA}

Hitt, Russell T. 1962. Cannibal Valley. Harrisburg: Christian Publication.

Lieshout, Frans. 2009. Sejarah Gereja Katolik di Lembah Balim-Papua: Kebudayaan Balim Tanah Subur Bagi Injil. Jayapura: Sekretariat Keuskupan Jayapura.

Luntungan, Cyrillus W. R. 2013. Baliem Budaya yang Tersisa dari Jaman Batu. Sunspirit Books.

Muller, Kal. 2009. Dataran Tinggi Papua. Daisy World Books.

Ngadimin, Stefanus. 1993. "Sistem Kepemimpinan Tradisional Suku Balim Sebagai Penunjang Pembangunan Daerah Jayawijaya" dalam Astrid S. SusantoSunario (ed.), Kebudayaan Jayawijaya dalam Pembangunan Bangsa. Jakarta: Pustaka Sinar Harapan.

Reuter, Susanne. 2010. Ketika Injil Bersinar di Yalimo. Wahine.

Silak, Ismael Roby. 2006. Hidup dan Kerja Para Penyiar Injil di Balim Yalimu. Penerbit Tabura.

Suroto, Hari. 2014. "Eksplorasi Peninggalan Arkeologi dan Etnoarkeologi di Kabupaten Mamberamo Tengah". Berita Penelitian Arkeologi No. 12. Balai Arkeologi Jayapura.

Zollner, Siegfried. 2006."Dampak Pekabaran Injil bagi Masyarakat Balim, Yali dan Mek" dalam Ismael Roby Silak (ed.) Hidup dan Kerja Para Penyiar Injil di Balim Yalimu. Penerbit Tabura. HIm. 28-43.

Zollner, Siegfried. 2011. Pohon Yeli dan Mitos Wam dalam Agama Orang Yali. Wahine.

\section{INTERNET}

http://www.lepido-france.fr/2009/12/quelques-heteroceres-de-la-pass-valleypapua/ diakses 30 September 2015

http://www.panoramio.com diakses 16 Januari 2016

http://www.pusatgidi.org/ind/selayang-pandang-0 diakses 16 Januari 2016 